\title{
Ecocultural Tourism in Tegal Regency
}

\author{
Siswo Harsono ${ }^{{ }^{*}}$ \\ ${ }^{1}$ Department of English, Faculty of Humanities, Diponegoro University, Semarang - Indonesia
}

\begin{abstract}
Ecocultural tourism is a hybrid of ecotourism and cultural tourism. This research deals with ecocultural tourism in Tegal Regency, Central Java, Indonesia. The purpose of this research is to investigate the hybridity of ecotourism and cultural tourism in the Tegal Regency. This research uses ecocultural theory and ecocultural tourism theory. The methods applied in this research are library research and fieldwork. Library research is applied to collect informative data about ecocultural tourism. The fieldwork is applied to collect data by interviewing the informants of tourism in Tegal Regency. By applying the theory and the methods, it is found that the hybridity of ecotourism and cultural tourism becomes the strategy to develop ecocultural tourism in Tegal Regency. On the one hand, ecocultural events relate to natural conservations; on the other hand, the events related to cultural conservations. The ecocultural tourism events become the prime tourist attractions that are able to attract local, domestic, and foreign tourists.
\end{abstract}

Keywords: ecotourism; cultural tourism; ecocultural tourism; ecocultural conservation.

\section{Introduction}

The purpose of this research is to investigate the hybridity of ecotourism and cultural tourism, to be ecocultural tourism. Ecocultural tourism is a hybrid of ecotourism and cultural tourism. There are two main research problems: first, how the hybridity of ecotourism and cultural tourism exist to be ecocultural tourism in Bumijawa District, Tegal Regency; second, how the ecocultural tourism to be a strategy of ecocultural conservations. Ecocultural events relate to natural and cultural conservations. This research is designed to be descriptive and qualitative. The research location is Bumijawa District, Tegal Regency, Central Java, Indonesia.

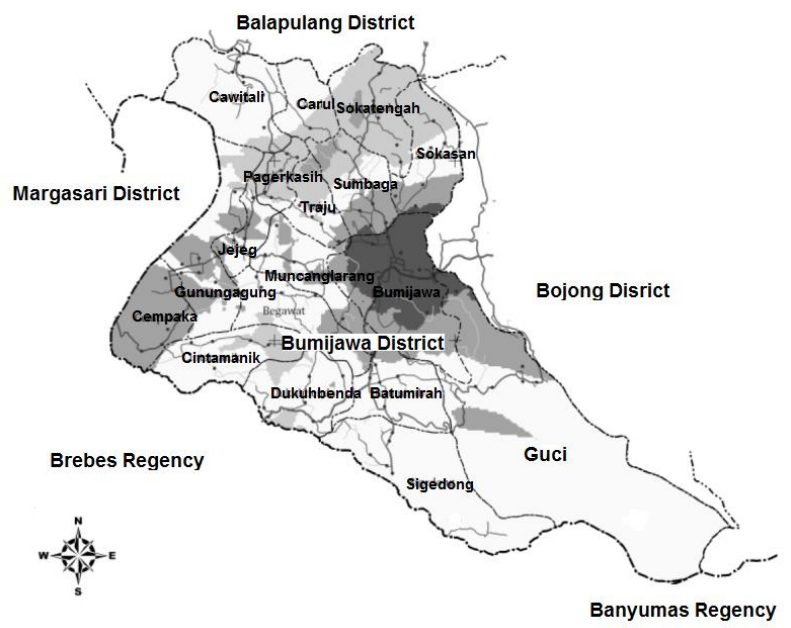

Fig. 1. The Map of Bumijawa district

\section{Theory and methods}

This research uses ecotourism, cultural tourism and ecocultural tourism theories. The methods applied in this research are library research and fieldwork.

Ecotourism deals with natural ecosphere of tourism objects. Cultural tourism deals with cultural activities held in the tourism objects. Ecocultural tourism can be defined as a hybridity of ecotourism and cultural tourism.

\subsection{Theoretical Definitions}

Ecotourism is outlined as environmentally accountable travel comparatively undisturbed natural areas so as to relish and appreciate nature that promotes conservation, that has low negative traveler impact and provided for beneficially active socio-economic involvement of native populations [1]. According to Jelisavka Bulatović and Goran Rajović, ecotourism is about uniting conservation, communities, and sustainable travel to minimize physical, social, behavioral, and psychological impacts; to assemble environmental and cultural focus and respect, grant high quality experiences for each visitors and hosts; to furnish direct monetary benefits for conservation; generate financial advantages for each local human beings and non-public industry; to deliver memorable interpretative experiences to traffic that help bring up sensitivity to host countries' political, environmental, and social climates; to design, assemble and function minimal impact facilities; to understand the rights and non-secular beliefs of the Indigenous; to work in partnership with human beings in your neighborhood and to create empowerment [2].

\footnotetext{
* Corresponding author: siswoharsono@live.undip.ac.id
} 
Tourism does not always have to represent globalization or the subjugation of local to tourists and the demands of the tourism industry. However, it should participate in local people to control their futures by applying ecotourism and cultural tourism. Cultural tourism will be outlined because of the movement of persons to cultural attractions far away from their residence, intending to collect new data and experiences to satisfy their cultural desires [3]. Cultural tourism presents great attractions for foreign tourists through the integration of cultural values [4]. Cultural tourism includes the offer which involves attractive artistic contents, both those related to the daily life of the local community, traditions, and festivals and those related to the presentation of tourism goods and the specificity of a particular locality [5].

The concept of eco-cultural tourism which is, therefore, a subset of ecotourism is framed by integrating ecotourism as a sustainable form of natural resourcebased tourism and its prevalent culture. This is a new form of tourist activity where both the ecological and cultural aspects of a landscape are combined to create a site for tourists. It can also be explained as travel to destinations where both the natural and cultural endowments are the prime attractions and considered to be a potential strategy to support the conservation of natural habitats, an exhibition of indigenous cultures and an alternative to economic sustainability [6]. Ecocultural tourism is delivered right here as a notion in which ecological and cultural elements of a landscape are blended to create a website for tourists. It is proposed as a way for communities within any different case marginal cultural or ecological property to improve [7]. By connecting cultural tourism to eco-tourism in this way, the focal point can probably empower that such an alliance affords indigenous people. Such tourism varieties, related to eco-cultural tourism, are sustainable and vary from mass tourism in earnings levels, distribution of reap and manage of the employer [8].

The hybridity of ecotourism and cultural tourism can be described as follows.

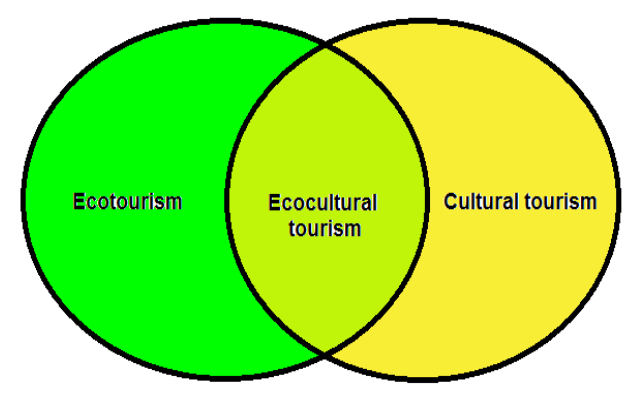

Fig. 2. Ecocultural hybridity

\subsection{Methods}

This research applies the methods of library research and fieldwork. The methods used in this study are (1) Library research is applied to collect the data of ecotourism and cultural tourism in Tegal Regency, especially in Bumijawa District. (2) Observation is done by conducting direct observations to get a clear picture of the conditions of tourist objects in Tegal Regency, especially in Bumijawa District. (3) An in-depth interview is carried out with key informants, staffs of the Tourism Office, staffs of Culture Service in Tegal Regency, community leaders, and tourism entrepreneurs. (4) Focus Group Discussion is conducted to facilitate dialogue with the community so that they can directly discuss to find out the perceptions of the community on ecotourism, cultural tourism, and ecocultural tourism [9].

\section{Findings and discussion}

Ecotourism in Bumijawa District, Tegal Regency, can be classified into mountain ecotourism, river ecotourism, and lake ecotourism. The mountain ecotourism includes Bukit Bintang (star hill) and Wana Wisata Guci. The river ecotourism is dominated by waterfalls and hot water bathing. Lake ecotourism includes Cempaka lake, Kaliwangun lake, and Kemadu lake. Cultural tourism consists of sedekah bumi, jamasan, and maulid. Ecocultural tourism consists of Guci earth caring, Guciku hot water boom, Guci forest tourism, and Sigeyong rafting and tubing. The percentage is ecotourism $75 \%$, cultural tourism $11 \%$, and ecocultural tourism $14 \%$.

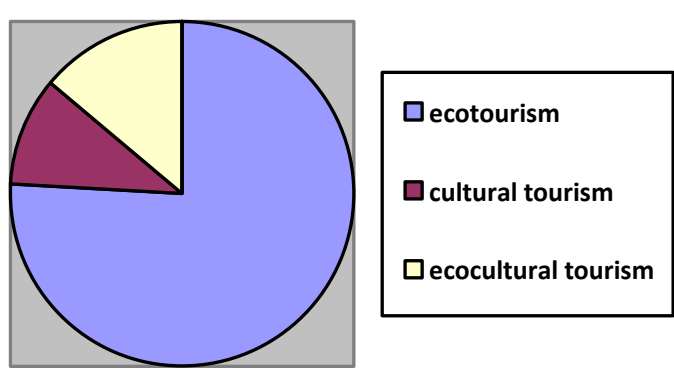

Fig. 3. Table of Bumijawa tourism

\subsection{Guci mountain ecotourism}

\subsubsection{Bukit Bintang}

Bukit Bintang (star hill) is located in Guci Village, Bumijawa District, Tegal Regency also offers a similar experience. But the difference is that the place is lonely and far away from air pollution, noise pollution, and light pollution. Each direction offers a different view. If looking north, see Bumijawa region to Tegal City. In the east, the sunrise and settlement of the people entering the village of Guci. The south side of Mount Slamet will look great. And the west itself will be seen the row of hills. Afternoon it is seen the hills and Mount Slamet, at night it is seen the stars and the lights of the resident's house. 


\subsubsection{Bukit Cepu}

Bukit Cepu is located in Krajan Hamlet, Batumirah Village, Bumijawa District, Tegal Regency, or about 24 $\mathrm{KM}$ to the south from the center of Tegal Regency. It is not easy to get to this place because there are only footpaths that are uphill, and all vehicles are parked under the hill. There is a kind of staircase from the ground which amounts to about 950 pieces.

\subsubsection{Wana Wisata Guci}

Wana Wisata Guci or Guci jungle ecotourism is one of ecotourism attractions near Guci hot springs, Bumijawa, Tegal Regency. Its beautiful natural scenery is a blend of woodland with vast hills of the hills, of course, this condition is highly regarded by visitors who have not felt the enjoyment of the beautiful ecotourism. As a family touristic area, the facilities are fairly complete, ranging from villas, adult pools to children, out bound, playground, tree house, resto, campground, paint ball, and Jedor waterfall. Nothing, almost every holiday season, this place is always full for rental villas. The towers of towering pine trees and cool atmosphere are guaranteed to reduce fatigue in daily activities. The swimming pool with warm water, poolside huts add to its own frenzy. For those who love adventure, try flying fox or rope bridges, or just walk down the river with beloved ones. They are all in one ticket only, except for the rental of a villa and a hall. The villa's choice is quite diverse, there are pine villas with standard buildings and villas made from bamboo.

\subsection{Guci river ecotourism}

\subsubsection{Jedor waterfall}

It is said that the name of this waterfall is taken from the village head of the village, Jedor Village. But do not look at his name, though his name is simple, this waterfall cannot be seen in your eyes. It is about $1 \mathrm{KM}$ from Shower 13 Thermal Baths This jewel has beautiful views. The location is quite hidden but easy to reach. It can be accessed by private car, motorcycle, even walking. Due to the easy access, there are 3 routes that can be taken, namely via Guciku, Wana Wisata Guci (jungle ecotourism), or via Shower 13. But the recommendation is the Wagu route because the scenery is more beautiful and the road is also suitable for trekking. While exercising and of course, tourists will get cool air. If through this line, the tourists will find two waterfalls at once, namely Kaliawu River.

\subsubsection{Kaliawu waterfall}

Kaliawu waterfall is one of the small waterfalls in the Perhutani Guci complex because the current is not so great but despite the mini, the waterfall is about 7 meters high. So the water comes out like water pouring from the tap. In addition to the cold and cool air, the scenic view of Kaliawu River is a towering pine forest. The curb's cliffs are shaped like a semicircle, so as if we were "surrounded" by the hill. The distinctive feature of this waterfall is to have an orange container on its hill wall. This is because the water from this waterfall contains sulfur although not as much as in the Hot Water Bath. The water in the pond is also not deep, below the adult knee. Because it is not in, tourists can see directly the rocks that are at the bottom of the water.

\subsubsection{Kaliputih waterfall}

Most of the new waterfalls found, can only be passed during drought as this is due to the security factor and easy access when it comes to stream flow. Ecotourism this time discusses about one of the waterfalls in the Kaliputih River, Guci Village, Bumijawa District, Tegal Regency, the residents call it Kaliputih waterfall.

\subsubsection{Kembar waterfall}

In fact this waterfall does not have a special name, but many people around it call it twin waterfall, yes, because there are two watercourses nearby. Almost similar to Penganten waterfall, one of its watercourses has a steady flow of water and the other is not too heavy. The Twin waterfall is located close to the Guciku Hot Waterboom, precisely next to the Villa Syariah, enter the Village Guci, Bumijawa District, Tegal District. But we have to go downstairs, but be careful because the road is pretty slippery. Just a few yards walk just past the rice fields we can reach the waterfall which has an altitude of about 5 meters.

\subsubsection{Sigeyong waterfall}

There is another waterfall that is still in existence, Sigeyong waterfall. The location is not so visible from the top of the bridge. If we stay at a nearby inn, just a short walk away, only about 70 meters from the bridge, we can enjoy this mini waterfall. The height of the waterfall is about 4 meters if we stand above the bridge, this waterfall is not so noticeable. What is seen is simply a not so large stream of stream that stops on a stream line. If we drift down the street, it looks like a waterfall with its beautiful walled walls extending downward.

\subsubsection{Gung waterfall}

Gung waterfall has an altitude of about 6 meters with a water discharge that tends to be strong but is categorized as safe to be under the waterfall during rainy days in the upstream of the Gung River. Water down from the top of this waterfall can be a reflection massage facility by tourists. The water drops from the top as it helps to relax the tense muscles.

\subsubsection{Cantel waterfall}

Cantel waterfall is located at the Kalipedes hamlet, Sigedong Village, Bumijawa District, Tegal Regency, this location is quite difficult to reach. Because it takes a 
long enough tracking down the river with a large enough rock. We are required to track as much as 400 meters from the highway by the river stream. Cantel Waterfall is about 60 meters high. So imagine how high this waterfall is. Splashing waterfall will instantly feel the face once it arrives at this location. It is not advisable to shower under the waterfall, because the water dropped so strongly. The tracking field in this place is quite unique, as tourists should walk between two sides of a hill separated by a small stream.

\subsubsection{Penganten waterfall}

The location of Penganten waterfall itself is above Luhur Waterfall which is about 500 meters away. Just walk a few minutes to fight the flow of the river, tourists have arrived at the waterfall which amounts to two of these. This waterfall sourced from the Gung River has a height of about 10-14 meters. Administratively, the Penganten waterfall is included in the Bandarsari Hamlet area, Bumijawa Village, Bumijawa District, Tegal Regency. In the waterfall to the right of the direction of flow the water tends to fall downwards, while the waterfall of the pair, the direction of the flow tends to radiate with a more rapid flow. That is why the waterfall is called the bride waterfall. Although the direction of the flow is different, the direction of the water will still lead to the same pool of water. The walls of the waterfall are overgrown with moss plants and vines.

\subsubsection{Luhur waterfall}

Luhur waterfall is located between Sokasari Village, Bumijawa District, and Tuwel Village, Bojong District (Kopigandu hamlet) and all of them are in Tegal Regency, which has a height of about 25 meters. Because of its position in the mountains, cool air will be felt in this place. This waterfall is very beautiful, this waterfall seems to be in a large pool bowl whose water is only solely the feet of an adult with clear water. So that we can immediately see the small rocks below. On the cliffs are overgrown with moss, trees that propagate, and the roots of the trees that sock from behind the cliff.

\subsubsection{Longan waterfall}

In the Bumijawa area, there is another beautiful Longan waterfall. The word "longan" in Javanese means "under". Maybe because the location of the waterfall is under the bridge that crosses over the Gung River, but it can be seen from the bridge because it is flanked by two hills. The hill is like a reverse boat shape.

\subsubsection{Monkey waterfall}

Monkey Waterfall is one of the waterfalls or waterfalls in Gunung Guntur Hamlet, Cawitali Village, Bumijawa District, Tegal Regency. It is predictable from his name that many wild monkeys were hanging around in this place. This waterfall is used as a myth by local residents so that the waterfall remains natural. This waterfall holds its charm with a height of about 25 meters and has quite heavy water even in the dry season. Under the waterfall, there are quite a lot of rocky rocks. So that it can be used to just sit around while enjoying the surrounding scenery and the splash of water.

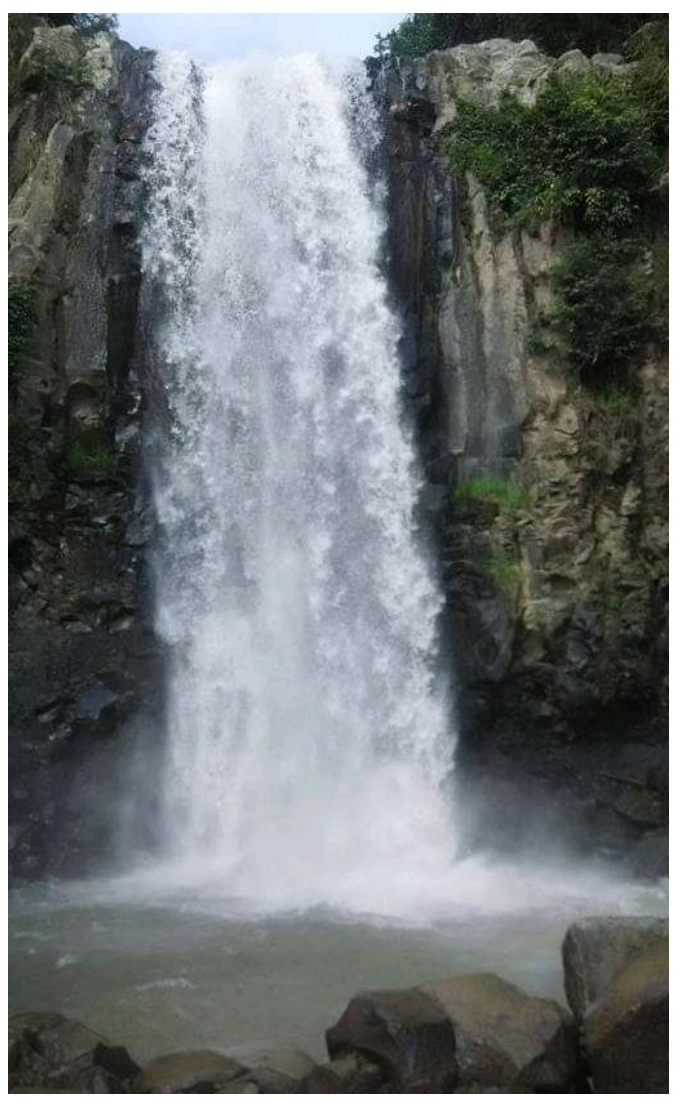

Fig. 4. Monkey waterfall

\subsubsection{Kalidiang waterfall}

Kalidiang waterfall has clear water and cold air. With a nerrow river, the trip is more challenging, having to break through several transverse and fallen trees. Large rocks also add to the excitement of the trip.

\subsubsection{Cawitali bride waterfall}

Cawitali bride waerfall is located in Cawitali Village, Bumijawa District, Tegal Regency. The waterfall which has three water flows is indeed not so high, only about 7 meters. It is in a land overdraft, where the steep cliff consists of natural large rocks, which have almost no vines on the walls of the hill. The shape of the rock is also quite unique, similar to the human face that uses a crown with eyes closed but with a gaping mouth. There is a stone for meditating because of its flat shape but its position at a high place. Moreover, the atmosphere is also quiet, there is only the sound of splashing water.

\subsubsection{Sentul waterfall}

Sentul waterfall is located in Lemah Abang Hamlet, Cawitali Village, Bumijawa District, Tegal Regency. As a place for fishing, it is also used as a repelling training 
ground. Because indeed the wall of the waterfall is quite steep and has a height of about 20 meters. It is quite unique because at the base of the wall there is an overdraft of land in the direction that is shaped like a cave. Despite the dry season, the water is quite heavy and cold, and near the cave, the atmosphere is cooler.

\subsubsection{Jejeg waterfall}

Jejeg waterfall sourced from Kali Sier is located in Jejeg Village, Bumijawa District, Tegal Regency. This waterfall is still beautiful and has rocks that can be occupied while enjoying the splash of water coming down from the hill. The height of the waterfall is around 22 meters. In the dry season, the water is not too heavy, so it is safe and comfortable. The water condition is not too clear, but the temperature of the water is quite cold. There are no public facilities around it, there are only a few houses or activities of residents around the river.

\subsubsection{Guci hot water}

Guci is located in Guci Village, Bumijawa District, below the foot of Mount Slamet. Many hills, rivers, plantations are found on the approach. In Guci, tourists can feel the fresh air and also the air cool enough. There are open, covered, and swimming pools. There is a horse rental too. The hot water in Guci can heal the skin.

\subsection{Guci Lake Ecotourism}

\subsubsection{Cempaka Lake}

Cempaka Lake is located in Cempaka Village, Bumijawa District, Tegal Regency. This natural source of clean water is used by local residents for daily needs and is used to irrigate the surrounding fields so that the fields and irrigation canals are near this spring. A beautiful and cool atmosphere makes you feel at home here. There are many shady trees and mountains surrounding the spring. Although it doesn't look clear, the water temperature here is cold because it is on a plateau. The lake pond area is around $15 \mathrm{~m} 2$ with a depth of 1 meter more.

\subsubsection{Kaliwangun Lake}

Kaliwangun Lake is located in the Kaliwangun area, Muncanglarang Village, Bumijawa District, Tegal Regency. This lake is still beautiful, clean and cool. The lake which is half of the soccer field has a depth of about 1 meter on the edge and 2 meters in the middle of the lake. The water is clear so that the bottom of the lake looks straight. But at the bottom of the lake, there are many water plants and several small fishes that went back and forth. On the edge of the lake, there is a large tree like a banyan tree and several other trees that add to the beautiful atmosphere. There are also several dead tree trunks that appear on the surface of the water.

\subsubsection{Kemadu Lake}

Kemadu Lake is a source of water for residents of Pereng Hamlet, Muncanglarang Village, Bumijawa District, Tegal Regency for daily needs. But gradually this lake changed its function to become a place of recreation and finally managed independently by local residents so that it became an attractive natural tourism object. The towering trees accompanied by the cool atmosphere typical of the mountains become a daily sight. Several duck boats have also been prepared at the edge of this lake that is rented out to tourists. There are several gazebos that stand beautifully on the outskirts of the lake, prayer room, and simple food stalls belonging to the residents. Even though the function has changed to become a tourist place, local residents still use it for their daily needs, especially for bathing and washing.

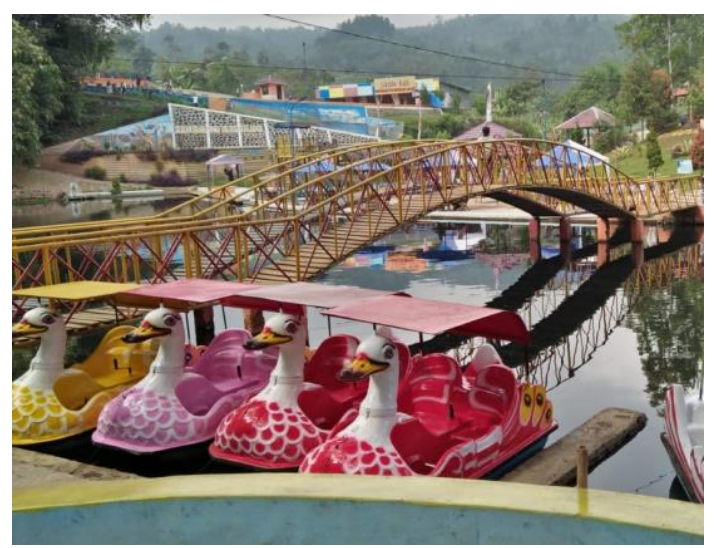

Fig. 5. Kemadu Lake

\subsection{Guci Cultural Tourism}

Guci cultural tourism includes Ruwat Bumi Guci, Maulid celebration parade, and Jamasan Tuk Bulakan.

\subsubsection{Guci earth caring}

Guci earth caring is an annual tradition held by the residents of Guci Village and surrounding villages. This routine tradition performed during Muharram month is intended as an expression of the people's gratitude to God Almighty and rejecting danger. After the procession of bathing goats, it is followed by the ritual and reading of Guci's history by the officer in Tegalan Language. There are some celebrations such as a gunungan, prayer and special dance of Tegal. This event is promoted as a cultural tourism agenda in the surrounding community. Every year, the event is always accompanied by both local and foreign tourists. It is also a means to boost the interest of tourists to return to the tour in Guci. Especially at this time, due to tourist worries due to Mount Slamet status. So, this event can also be a socialization event that Hot Water Bathing is still safe to visit. 


\subsubsection{Maulid celebration parade}

The parade held in Bumijawa is different from the other Maulid celebrations of the Prophet Muhammad SAW elsewhere that only show the line-up of parade participants only, because the parade is always held on the night of the anniversary of the Prophet Muhammad SAW in Rabiul Awal Hijriyah. Even from other areas do not know much about this rally. Each Rukun Tetangga (neighbor association) in Bumijawa District each year gets a parade sequence to feature religious rallies. Especially the religion of Islam. Not only marches, but every neighbor association is also required to make an appearance while passing ahead of the tribal stage.

\subsubsection{Jamasan Tuk Bulakan}

Tuk Bulakan is the source of the springs in Bulakan, Bumijawa. It is said that there is a kenong found one of the brass instruments made of brass that covered the springs. Mbah Cemuluk saw the birds humped the ground that was found in a kenong. Mbah Cemuluk curiously took the kenong and immediately the sparkling spring now called Tuk Bulakan. From the story, the descendants of Mbah Cemuluk rescued the kenong and every night 10 Rabiulawal / Maulud (Javanese calendar), kenong and dozens of relics of Cemuluk's grandmother like keris, pottery pot, and other things were done jamasan. This procession is done directly by the key caretaker or descendant of Mbah Cemuluk and is held in the rarely opened Tuk Bulakan building. There is a show of ebeg or a lumping horse to enliven this event. Every year, this procession is always full of people to see this cultural heritage directly, as well as seeing the inside of Tuk Bulakan with clear water and can be drunk.

\subsection{Guci ecocultural tourism}

\subsubsection{Guci earth caring}

Guci earth caring, an annual tradition control by the residents of Guci Village, is a practice of caring for the earth. There is a procession for bathing a black and white goat in Shower 13 by the regents and community leaders, and it's followed by ritual and reading of Guci's history by the officer, using Tegalan Language. There is a number of the celebrations such as a gunungan, prayer and Tegal special dance. This event is promoted as an ecocultural tourism agenda in Tegal Regency. Every year, the event is usually amid native and foreign tourists. Earth caring is additionally a method to spice up the interest of tourists to come back to the tour in Guci. Particularly because holidaymaker worries due to Mount Slamet standing, this event may also be a socialization event that quandary Baths are still safe to go to.

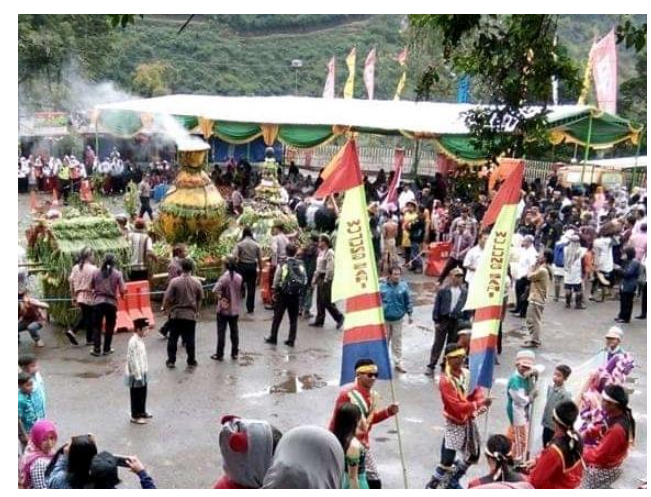

Fig. 6. Guci earth caring

\subsubsection{Guciku hot waterboom}

Guciku Hot Waterboom is located near the ticket window to Guci, in Guci Village, Bumijawa District, Tegal Regency. As the name implies, this place has a waterboom, aka a water game. This place is divided into four areas: Opal Pool for children's play, Jars Body Pool for teenagers, Soak Pool with hot water showers which are believed to be healthy and cure various diseases, and the Main Pool is equipped with spiral play and slides.

\subsubsection{Guci forest ecocultural tourism}

Guci forest ecotourism is certainly one of the ecotourism attractions near Guci hot springs, Bumijawa, Tegal Regency. Its lovely herbal surroundings are a blend of woodland with good sized hills, of the route, it is as the amusement of the stunning ecotourism. However, it also can be classified into ecocultural tourism because it relates to the centers that are pretty complete, ranging from villas, adult swimming pools to kids, outbound, playground, tree residence, restaurant, campground, paintball, and Jedor waterfall. In each vacation season, rental villas are always full. For those who love journey, strive flying fox or rope bridges, or simply walk down the river with the loved ones. The towers of pine trees and cool atmosphere are assured to reduce fatigue in day by day sports. The swimming pool with hot water, poolside huts add to its very own frenzy. There are pine villas with ecofriendly buildings of bamboo villas.

\subsubsection{Sigeyong rafting and tubing}

In Sigeyong there are Fun Guci Mini Rafting and tubing. Fun Mini Rafting includes level 1 rafting, because the flow is still flat and is an irrigation channel that is only 1.4 meters wide with a depth of $60 \mathrm{~cm}$. So it's safe for those who want to go rafting with family. The distance traveled is only $1 \mathrm{~km}$. Tubing is a game that uses inner truck tires. There are three choices of routes that can be chosen, there are relaxed route, extreme fun, and extreme lines. The location is the same as the Guci Mini Rafting Fun, which is on the iron bridge going to Guci. 


\section{Ecocultural conservations}

Guci earth caring is a thanksgiving ceremony that relates to natural and cultural conservations. Naturally speaking, it conserves the sustainability of Guci ecotourism. Culturally speaking, it also conserves the sustainability of Guci cultural tourism. Maulid celebration parade relates to ecocultural conservation. Naturally, it refers to the use of environmental wealth to support its creativity. Culturally, it conserves maulid tradition in locally creative way of the folks of Bumijawa. Jamasan (water caring) Tuk Bulakan is also ecocultural conservation that relates to natural and cultural ones. Naturally, the water springs should be cleaned from water pollution. Culturally, the cleaning process relates to the folklore conservation of Mbah Cemuluk and folk belief that it will be kept away from danger. This kind of rejecting danger relates to the sustainability of Tuk Bulakan.

The relation between natural conservation, cultural conservation, and ecocultural conservation is illustrated as follows.

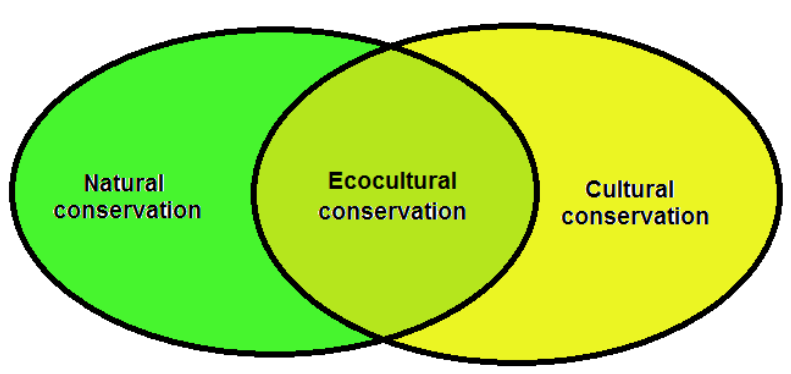

Fig. 7. Ecocultural conservation

\section{Conclusion}

Ecocultural tourism is a combination of ecotourism and cultural tourism. Ecotourism in Bumijawa District, Tegal Regency consists of mountain ecotourism, river ecotourism, and lake ecotourism. Mountain ecotourism includes hill ecotourism and jungle ecotourism. River ecotourism includes waterfall ecotourism, hot water springs, and hot waterboom. Lake ecotourism consists of water spring ecotourism. Cultural tourism in Tegal Regency consists of ruwatan, jamasan, and celebration. Ruwatan relates to thanksgiving and rejecting danger to care world like Guci earth caring. Jamasan relates to water caring like in Tuk Bulakan. Celebration relates to thanksgiving like in Maulid celebration parade. Ecocultural tourism relates to natural and cultural conservations. Natural conservation deals with the sustainability of ecotourism. Cultural conservation concerns with the sustainability of cultural tourism. It can be concluded that ecocultural conservation is not only eco-friendly but also culture-friendly to maintain ecotourism in Tegal Regency.

\section{References}

1. H.C. Lascurian, Tourism, Ecotourism and Protected Areas, ICUN, Gland, Switzerland (1996)
2. B. Jelisavka, G. Rajović, Some Aspects of Eco Tourism with View to Montenegro: Overview, Journal of Advocacy, Research and Education 4(2), 96-111 (2017)

3. G. Richards, What is Cultural Tourism? In van Maaren, A. (ed.) Erfgoed voorToerisme, Nationaal Contact Monumenten (2003)

4. L. Hincu, Promoting the Bucovina Aarea on Cultural and Religious Tourism, Ecoforum 6(3), 1$21(2017)$

5. Ilinicic, Marina, D. Jovicic, Persepectives of Cultural Tourism in the Modern Tourism Market, GSGD 95(1), 31-50 (2015)

6. L. Cajee, Eco-Cultural Tourism: A Tool for Environmental, Cultural and Economic Sustainability (A Case Study of Darap Village, West Sikkim), SHS Web of Conferences 12, 0102 (2014)

7. G. Wallace, A. Russell, Eco-cultural tourism as a means for the sustainable development of culturally marginal and environmentally sensitive regions, London: Sage Publications TS. 4(3), 235-254 (2004)

8. G. Wallace, The Contribution of Cultural Tourism to the Development of Sustainable Tourism, 225-33 in P. Kakouros (ed.), Tourism in Protected Areas in Greece, Symposium Proceedings, Sitia, Crete, (2002)

9. A.S. Sulitiyawati, Pengembangan Ekowisata Berbasis Kerakyatan di Banjar Nyuh Kuning, Desa Mas, Ubud, Ecotrophic JoE S. 6(2), 128-132 (2015) 